\title{
Bacteriological Profile and Anti Microbial Susceptibility Pattern of Neonatal Sepsis in a Tertiary Care Hospital
}

\author{
Meerah Srinivasagam*, Vijayalakshmi Arumugam and Rajeswari Jayakumar \\ Department of Microbiology, Chengalpattu Medical College, \\ Chengalpattu, Kanchipuram District, Tamilnadu, India \\ *Corresponding author email id:
}

\begin{tabular}{|c|c|}
\hline \multicolumn{2}{|r|}{ A B S T R A C T } \\
\hline & \multirow{6}{*}{$\begin{array}{l}\text { Neonatal sepsis refers to systemic and generalized infection of the newborn which is } \\
\text { documented by a positive blood culture in the first four weeks of life. It is one of the four } \\
\text { leading causes of neonatal mortality in India, to isolate bacterial pathogens in neonates } \\
\text { with clinical suspicion of sepsis from blood samples and to study their antimicrobial } \\
\text { susceptibility pattern. Blood samples collected from } 1072 \text { neonates with suspected sepsis } \\
\text { were processed. Out of } 1072 \text { neonates } 231(21.54 \%) \text { were culture positive. } 122(52.81 \%) \\
\text { of bacterial pathogens were isolated in early onset sepsis and } 109(47.18 \%) \text { in late onset } \\
\text { sepsis. Among the isolated bacteria } 126(54.55 \%) \text { were Gram negative and } 105(45.45 \%) \\
\text { were Gram positive. Klebsiella species and Staphylococcus aureus were the predominantly } \\
\text { isolated organisms. Anti microbial susceptibility pattern revealed that Piperacillin- } \\
\text { Tazobactum and Imepenem were the two most effective antibiotics against Gram negative } \\
\text { bacteria and Vancomycin and linezolid still remains the most effective drug for } \\
\text { Staphylococcus aureus. In neonatal sepsis knowledge of the commonly isolated organism } \\
\text { and their anti- microbial susceptibility pattern in our geographical area, aids in the } \\
\text { selection of appropriate antimicrobials for therapy. }\end{array}$} \\
\hline Keywords & \\
\hline $\begin{array}{l}\text { Early onset } \\
\text { Late onset } \\
\text { Pathogens. }\end{array}$ & \\
\hline Artic & \\
\hline $\begin{array}{l}\text { Accepted: } \\
\text { 23 June } 2017 \\
\text { Available Online: } \\
\text { 10 July } 2017\end{array}$ & \\
\hline & \\
\hline
\end{tabular}

\section{Introduction}

Neonatal sepsis refers to systemic and generalized infection of the newborn which is documented by a positive blood culture in the first four weeks of life. It is one of the four leading causes of neonatal mortality in India (Agnihotri et al., 2004). It is characterized by variable systemic physiologic changes triggered by infection, which continues to provide an extraordinary challenge to clinicians who manage critically ill neonates and children (Wynn et al., 2010). It is estimated that up to $20 \%$ of neonates develop sepsis and approximately $1 \%$ die of sepsis related causes (Stoll, 1997). Current neonatal mortality rate in India is $27 / 1000$ live births (UNICEF, 2012). Neonatal sepsis has been classified as early onset sepsis (EOS) and late onset sepsis (LOS).Early onset sepsis presents within 72 hours of life. The source of infection is vertical transmission during labour or nosocomial. The neonate usually presents with respiratory distress, and pneumonia. The presence of the following risk factors like low birth weight babies, meconium stained liquor, premature rupture of membrane, prolonged labour has been associated with an increased risk of EOS (Aggarwal et al., 2001; Belady et al., 1997; 
Kaftan et al., 1998). Late Onset Sepsis (LOS) usually presents after $72 \mathrm{hrs}$ of birth. The source of infection is either nosocomial or community acquired and neonates usually present with septicemia, pneumonia or meningitis (Baltimore, 1998; Wolach, 1997).

In most developing countries, Gram negative bacteria remain the major cause of neonatal sepsis (Anwer et al., 2000). These organisms have developed increased drug resistance over the last two decades, since the spectrum of organisms that causes neonatal sepsis changes over time and varies from region to region, it is necessary to conduct periodic surveillance to access the changing pattern of organisms causing neonatal sepsis. The gold standard for diagnosis of septicemia is the isolation of pathogen from blood culture (Nwadioha et al., 2010).

Hence the present study was undertaken to study the bacteriological profile of neonatal septicemia cases and their antibiotic susceptibility pattern for planning strategy for the management of these cases.

\section{Materials and Methods}

Neonates with a clinical diagnosis of sepsis admitted in pediatric ward in a Tertiary care hospital attached to Medical College, during the period of June 2016-May 2017 were included in this retrospective study. About 1072 blood samples collected were processed by standard microbiological method. Antibiotic sensitivity testing was performed by Kirby- Bauer disc diffusion method as per CLSI guidelines.

\section{Results and Discussion}

Out of 1072 cases $231(21.54 \%)$ were culture positive and $841(78.45 \%)$ were culture negative. $132(22.56 \%)$ of males and 99 $(20.32 \%)$ of females were culture positive.
Among the culture positive cases 122 $(52.81 \%)$ were early onset sepsis (EOS) and $109(47.18 \%)$ were late onset sepsis. $99(42.86 \%)$ of term babies and $132(57.14 \%)$ of pre-term babies were culture positive. 102 (44.15\%) of culture proven septic neonates had birth weight of more than 2500 gms which is appropriate for gestational age (AGA), and $129(55.84 \%)$ were low-birth weight (LBW) less than 2500 gms (Tables 1$3)$.

Among the culture positive cases 126 $(54.55 \%)$ were Gram negative bacteria and 105 (45.45) were Gram positive bacteria. Predominant Gram negative bacteria were Klebsiella species followed by Escherichia coli. Staphylococcus aureus was the predominant gram positive bacteria. Antimicrobial susceptibility pattern showed $27.43 \%$ of Klebsiella species, $12.5 \%$ of Escherichia coli, and $20 \%$ of $P$. aeruginosa were multi drug resistant. About $16.22 \%$ of Staphylococcus aureus were MRSA (Table 4).

In our study, positive blood cultures were found in $231(21.54 \%$ ) of clinically suspected neonatal sepsis cases, similar to the results of previous studies by Hura Kanwaljeet Singh et al., (2016); Khan et al., (2012) and Kenneth Iregbu et al., (2006).

Among the culture positive cases 132 $(22.56 \%)$ of males and $99(20.32 \%)$ of females were culture positive. This male predominance might be because of the importance given to the male infants and also because of more number of male infants born compared to female infants born (Jyothi et al., 2013).

Among the culture positive cases 122 $(52.81 \%)$ were early onset sepsis (EOS) and 109(47.18\%) were late onset sepsis (LOS) which was almost similar to the findings of 
Jyothi et al., (2013). Most of the cases were detected by blood culture occurred in the first week of life, calls for close monitoring of the newborns especially those in high risk categories as soon as they born. 99(42.86\%) of term babies and $132(57.14 \%)$ of preterm babies were culture positive. 102(44.15\%) of culture proven septic neonates had birth weight of more than $2500 \mathrm{gms}$, and 129 (55.84\%) neonates had low birth weight
(LBW) of less than 2500 gms. Most of the cases hospitalized were low birth weight babies and the preterm babies which were found similar to the study showed by Rania Mohammed Kishk et al., (2014). In the present study Gram negative bacteria with 126 (54.55) isolates constituted major group of pathogens causing neonatal sepsis which correlates with the findings of Kumhar et al., (2002); Hura Kanwaljeet Singh et al., (2016).

Table.1 Samples showing culture positivity and gender distribution

\begin{tabular}{|l|l|l|l|}
\hline Blood culture & Male & Female & Total \\
\hline positive & $132(22.56 \%)$ & $99(20.32 \%)$ & $231(21.54 \%)$ \\
\hline negative & $453(77.43 \%)$ & $388(79.67 \%)$ & $841(78.45 \%)$ \\
\hline Total & $585(100 \%)$ & $487(100 \%)$ & $1072(100 \%)$ \\
\hline
\end{tabular}

Table.2 Cases according to age of onset and culture positivity

\begin{tabular}{|l|l|l|}
\hline Age of onset & Positive & Negative \\
\hline EOS & $122(52.81 \%)$ & $453(53.86 \%)$ \\
\hline LOS & $109(47.19 \%)$ & $388(46.14 \%)$ \\
\hline Total & $231(100 \%)$ & $841(100 \%)$ \\
\hline
\end{tabular}

Table.3 Culture proven septic neonates as per gestational age (GA) and birth weight

\begin{tabular}{|l|l|}
\hline \multicolumn{2}{|c|}{ Culture Positive cases n=231 (100\%) } \\
\hline Term & $99(42.86 \%)$ \\
\hline Preterm & $132(57.14 \%)$ \\
\hline Weight AGA $>2500 \mathrm{~g}$ & $102(44.15 \%)$ \\
\hline LBW $<2500 \mathrm{~g}$ & $129(55.84 \%)$ \\
\hline
\end{tabular}

Table.4 Bacterial isolates in blood culture

\begin{tabular}{|c|c|c|c|}
\hline \multicolumn{5}{|c|}{} & LOS & Total \\
\hline Organism & EOS & 51 & $113(48.92 \%)$ \\
\hline Klebsiella spp & 62 & 33 & $74(32.03 \%)$ \\
\hline S. aureus & 41 & 18 & $31(13.42 \%)$ \\
\hline CoNS & 13 & 3 & $8(3.46 \%)$ \\
\hline E. coli & 5 & 4 & $5(2.17 \%)$ \\
\hline P. aeruginosa & 1 & 109 & $231(100 \%)$ \\
\hline Total & 122 & &
\end{tabular}



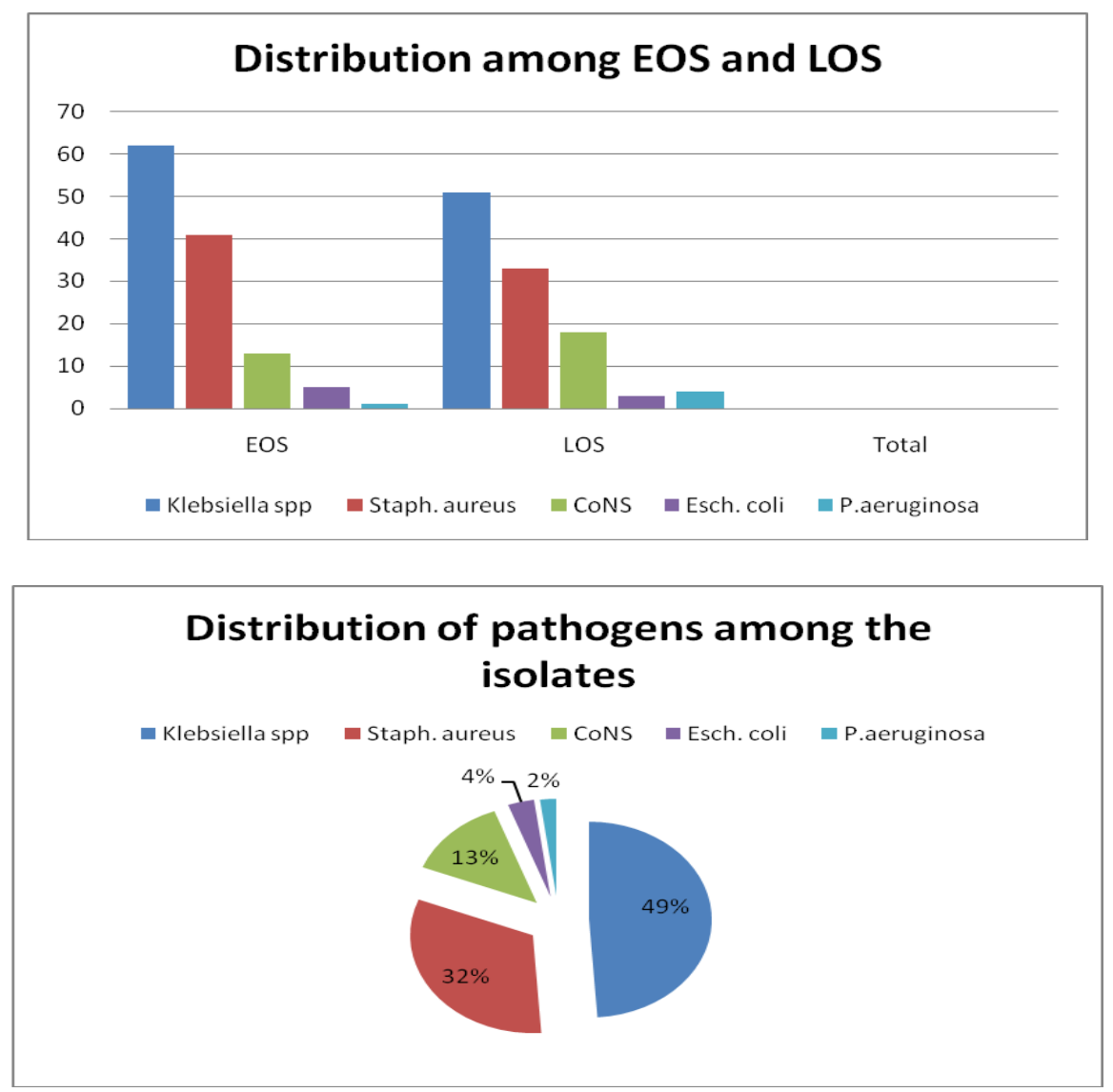

Table.5 Antibiotic sensitivity pattern of Gram positive isolates

\begin{tabular}{|c|c|c|}
\hline Antibiotics & Staph (74) & CoNS (31) \\
\hline Penicillin & $32(43.24 \%)$ & $28(90.32 \%)$ \\
\hline Gentamicin & $37(50 \%)$ & $26(83.87 \%)$ \\
\hline Cefoxitin & $62(83.78 \%)$ & $30(96.77 \%)$ \\
\hline $\begin{array}{c}\text { Vancomycin } \\
\text { (E-Test }\end{array}$ & $74(100 \%)$ & $31(100 \%)$ \\
\hline Linezolid & $74(100 \%)$ & $31(100 \%)$ \\
\hline
\end{tabular}

Table.6 Antibiotic sensitivity pattern for Gram negative bacterial isolates

\begin{tabular}{|c|c|c|c|}
\hline Antibiotics & Klebsiella spp (113) & $\begin{array}{c}\text { Esch. Coli } \\
(8)\end{array}$ & P. aeruginosa (5) \\
\hline Ampicillin & - & $1(12.5 \%)$ & - \\
\hline Amikacin & $76(67.25 \%)$ & $7(87.5 \%)$ & $3(60 \%)$ \\
\hline Cefotoxime & $55(48.67 \%)$ & $5(62.5 \%)$ & - \\
\hline Ceftazidime & - & - & $4(80 \%)$ \\
\hline Piperacillin/Tazobactum(PIT) & $82(72.57 \%)$ & $6(75 \%)$ & $3(60 \%)$ \\
\hline Imipenem & $113(100 \%)$ & $8(100 \%)$ & $5(100 \%)$ \\
\hline Meropenem & $113(100 \%)$ & $8(100 \%)$ & $5(100 \%)$ \\
\hline
\end{tabular}


Table.7 Multi-drug resistance among Gram negative bacteria

\begin{tabular}{|l|l|l|l|}
\hline & Klebsiella spp. $(\mathrm{n}=113)$ & Escherichia coli (n=8) & $\begin{array}{l}\text { P. aeruginosa } \\
(\mathrm{n}=5)\end{array}$ \\
\hline $\begin{array}{l}\text { No. of MDR } \\
\text { isolates }\end{array}$ & $31(27.43 \%)$ & $1(12.5 \%)$ & $1(20 \%)$ \\
\hline $\begin{array}{l}\text { Antibiotic } \\
\text { categories }\end{array}$ & $\begin{array}{l}\text { 1.Aminoglycosides } \\
\text { 2.Extended spectrum } \\
\text { cephalosporins } \\
\text { 3.Anti-pseudomonal } \\
\text { penicillin + beta } \\
\text { lactamase inhibitor }\end{array}$ & $\begin{array}{l}\text { 1.Penicillins } \\
\text { 2.Aminoglycosides } \\
\text { 3.Extended spectrum } \\
\text { cephalosporins } \\
\text { 4.Anti-pseudomonal } \\
\text { penicillin + beta } \\
\text { lactamase inhibitor }\end{array}$ & $\begin{array}{l}\text { 1.Aminoglycosides } \\
\text { cephalosporins } \\
\text { 3.Anti-pseudomonal } \\
\text { penicillin + beta } \\
\text { lactamase inhibitor }\end{array}$ \\
\hline
\end{tabular}

Among them, with 113 (48.92\%) isolates Klebsiella species has been found to be the predominant pathogen which correlates with the findings of Madhu Sharma et al., (2002) 105 $(45.45 \%)$ of Gram positive organisms observed in our study coincides with I Roy et al., (2002): Among the Gram positive organisms with 74 isolates (32.03\%) Staphylococcus aureus was the dominant pathogen.

Results of the antimicrobial susceptibility pattern revealed that $33(26.19 \%)$ of the Gram negative organisms were multi-drug resistant. It has been shown that PIT, Imepenem and meropenem are the two most effective antibiotics against Gram negative organisms. Among the Gram positive bacteria, 12(16.22 \%) of the Staphylococcus aureus were MRSA, and Vancomycin still remains the most sensitive drug for $S$. aureus, which correlates with findings of Roy et al., (2002) (Tables 5-7).

In conclusion, the present study showed that Gram negative bacteria were the most common cause of septicaemia in neonates, with Klebsiella species as the predominant pathogen. Most of the Gram negative bacteria were multidrug resistant and. Early detection of these strains is crucial to establish an appropriate antimicrobial therapy, thereby reducing the morbidity and mortality associated with these infections and also to prevent hospital acquired infections in neonates.
Formulating antibiotic policy and judicial use of higher antibiotics, strict aseptic precautions are the measures that can be taken to combat serious therapeutic challenge faced with emerging multi-drug resistant bacterial pathogen.

\section{References}

Aggarwal, R., Sarkar, N., Deorari, A.K., et al. 2001. Sepsis in the newborn. Indian J. Pediatr., 68(12): 1143-7.

Agnihotri, N., Kaistha, N., Gupta, V. 2004. Antimicrobial susceptibility of isolates from neonatal septicemia. Jpn. J. Infect. Dis., 57: 273-275.

Anwer, S.K., Mustafa, S., Pariyani, S., Ashraf, S., Taufiq, K.M. 2000. Neonatal sepsis: an etiologic study. J. Pak. Med. Assoc., 50: 91-94.

Baltimore, R.S. 1998. Neonatal nosocomial infection. Semin. Perinatol., 22(1): 25-32.

Belady, P.H., Farkouh, L.J., Gibbs, R.S. 1997. Intra-amniotic infections and premature rupture of membranes. Clin. Perinatol., 24(1): 43-57.

Bhutta, Z.A. 1999. Neonatal bacterial infections in developing countries: strategies for prevention. Semin. Neonatol., 4: 159-71.

Hura Kanwaljeet Singh, M.D., Phuljhele Sharja, M.D. and Khandwal Onkar, M.D. 2016. 
Bacteriological profile of Neonatal Sepsis in neonatal intensive care unit in a tertiary care hospital: Prevalent bugs and their susceptibility patterns, European $J$. Pharmaceutical Med. Res., 3(3): 241-245.

Joshi, S.G., Ghole, V.S., Niphadkar, K.B. 2000. Neonatal gram negative bacteremia. Indian J. Pediatr., 67: 27-32.

Jyothi, P., Metri, C., Basavaraj, Peerapur, V., Basavaraj. 2013. Bacteriological Profile of neonatal septicaemia and antibiotic susceptibility pattern of the isolates. $J$. Natural Sci. Biol. Med., 4(2): 306-309.

Kaftan, H., Kinney, J.S. 1998. Early onset neonatal bacterial infections. Semin. Perinatol., 22(1): 15-24.

Kenneth, C., Iregbu, Olumilayo, Y., Elegba and Iretiola, B., Babaniyi. 2006. Bacteriological profile of neonatal septicaemia in a tertiary hospital in Nigeria. Afr. Health Sci., 6(3): 151-154.

Kumhar, G.D., V.G. Ramchandran, Piyush Gupta, et al. 2002. Bacteriological analysis of blood clture isolates from neonates in a tertiary care hospital in India. J. Health Popul. Nutr., 20(4): 343347.

Madhu Sharma, Nidhi Goel, Uma Choudhary, Ritu Aggarwal, D.R. Arora, et al. 2002. Bacteraemia in children. Indian $J$. Pediatr., 69(12): 1029-1032.

Muhammad Aqeel Khan, Afzal Khan, Faridullah Shah, Arshia Munir. 2012.
Neonatal sepsis: A study of Causative pathogens and their antimicrobial sensitivity pattern at Tertiary Hospital. Gomal J. Med. Sci., 10(2): 244-47.

Nwadioha, S.I., Nwokedi, E.O.P., Kashibu, E., Odimayo, M.S., Okwori, E.E. 2010. A review of bacterial isolates in blood culturesof children with suspected septicaemia in a Nigerian tertiary hospital. African J. Microbiol. Res., 4(4): 222-225.

Rania Mohammed Kishk, Mohammed Fouad Mandour et al. 2014. Pattern of Blood Stream infections within neonatal intensive care unit. Int. J. Microbiol., 276873.

Roy, I., A. Jain, M. Kumar, S.K. Agarwal et al. 2002. Bacteriology of neonatal septicemia in a tertiary care hospital of northern India. Indian J. Med. Microbiol., 20(3):156-159.

Stoll, B.J. 1997. The global impact of neonatal infection. Clin. Perinatol., 24(1): 1-21.

UNICEF. 2012. The State of World's Children, $87-107$.

Wolach, B. 1997. Neonatal sepsis: pathogenesis and supportive therapy. Semin. Perinatol., 21(1): 28-38.

Wynn, J., Cornell, T.T., Wong, H.R., Shanley, T.P., Wheeler, D.S. 2010. The host response to sepsis and developmental impact. Paediatrics, 125(5): 1031-1041.

\section{How to cite this article:}

Meerah Srinivasagam, Vijayalakshmi Arumugam and Rajeswari Jayakumar. 2017. Bacteriological Profile and Anti Microbial Susceptibility Pattern of Neonatal Sepsis in a Tertiary Care Hospital. Int.J.Curr.Microbiol.App.Sci. 6(7): 2188-2193. doi: https://doi.org/10.20546/ijcmas.2017.607.317 